\title{
The Impact of Dynamic Capabilities and Information System on Organizational Effectiveness in cellular communication companies in Jordon: Mediating Role of Organizational Ambidexterity
}

\author{
Atif Aziz ${ }^{1, *}$, Ramsha Zaki ${ }^{2}$, Syed Ehsan Ullah ${ }^{3}$ \\ ${ }^{1}$ College of Management Sciences PAF-KIET University, Pakistan \\ ${ }^{2}$ Greenwich University Karachi, Pakistan \\ ${ }^{3}$ Universiti Utara Malaysia, Malaysia \\ 1 Atifraj2001@gmail.com* \\ * corresponding author
}

\begin{abstract}
The goal of the ongoing research is to examine the impact of dynamic capabilities such as exploitation capability, exploration capability and information system on the organizational effectiveness of cellular communication firms in Jordan. The examination of the mediating role of organizational ambidexterity among the nexus of dynamic capabilities such as exploitation capability and exploration capability and organizational effectiveness is also included in the goals of the ongoing research. The quantitative method of data gathering has been utilized by the researchers to collect the data from the employees of the cellular communication firms currently operating in Jordan while AMOS has been used for the purpose of analysis. The results exposed that the positive nexus has been found among the nexus of dynamic capabilities, organizational ambidexterity, and organizational effectiveness. The results also revealed that the organizational ambidexterity has positive mediating among the links of dynamic capabilities such as exploitation capability and exploration capability on organizational effectiveness. These findings are suitable for the regulation developing authorities that they should develop and implement the effective regulation related to the dynamic capabilities and organizational ambidexterity that enhance the organizational effectiveness of the firm.
\end{abstract}

Keywords: Dynamic Capabilities; Exploitation Capability; Organizational Effectiveness; Organizational Ambidexterity.

\section{Introduction}

The role of dynamic capabilities in the firms' organizational effectiveness has become one of the hottest issues which require long term and deep research and discussion among scholars. The success of an organization is in its organizational effectiveness in the fast-paced emerging economies [10]. Today firms have to confront much competition with others in the productivity, achievement of innovation, and superior quality in products and services, and more revenue. Firms also have to confront changes in the market circumstance, and customer preferences. To compete in the market business organizations set their organizational goals and past experiences of the firms prove that the achievement of the firms' organizational effectiveness achieves organizational goals possible. According to Dunham [8], Organizational effectiveness of a business enterprise is the perspective of how much effective is the enterprise in the achievement of outcomes that it intends to produce. Scholars are of the view that several organizational effectiveness groups are promoted in the business enterprises which are concerned with several key areas of the organization to check the organizational effectiveness. Organizational effectiveness can be judged through the leadership development, talent management, design and structure of the organization, design of scorecards and measurements, analysis and implementation of changes, utilization of smart procedures, and technology to deploy human capital and develop the strategies of human resource management [37]. The success of a business enterprise depends on the effectiveness of different organizational sectors. The more effective are the organizational departments and areas, the areas are the indicator of firms' organizations.

In fast-paced competitive economies, organizations adopt critical core capabilities, dynamic capabilities, to bring improvements in the organizational effectiveness in several organizational areas. The development and 
adoption of dynamic capabilities by the business organizations to create so much organizational effectiveness that the business organizations may compete against their rivals in the market are of great significance [4]. This paper intends to shed light on the impacts of the adoption of the dynamic capabilities (DC) in the achievement of organizational effectiveness in business firms with the several articles of evidence from the cellular communication companies in Jordon. A great investigation by researchers highlights the fact that, in Jordon, the cellular communication companies implement dynamic capabilities in their business operations and enjoy much more organizational effectiveness which is the source of their success. This study has been conducted to show the mediating effects of organizational ambidexterity on dynamic capabilities (DCs), organizational effectiveness, and their mutual relationship [11].

The set of dynamic capabilities is needed for the achievement of organizational effectiveness. The scholars who take the resource-based view (RBV) as an incomplete effort to achieve organizational effectiveness and competitive advantage have presented an arguing intellectual view in this context. They favor the dynamic capabilities (DCs) for the achievement of organizational effectiveness as a paradigm to sense the changes in the business environment and market demands, and to respond to these changes timely [33]. Supported by the research-based literature, Dynamic capabilities influence the firms' organizational effectiveness in two perspectives. First, it indicates the shifting role of the environment. Second, it helps to design and implement the managerial strategies to appropriately adapt, reconfigure and integrate firms' internal and external organizational competencies, their resources, organizational procedures, and functional abilities according to changes in the markets' requirements and customer preferences. Scholars and researchers have recently started to focus on the Dynamic capabilities to promote how abilities, skills, and strategies are renewed to react to the shifts in the market and overall business environment [38]. The audit of the cellular communication companies working in Jordon demonstrates the improvement in their organizational effectiveness by implementing dynamic capabilities approach which enables them to redeploy, integrate, and reconfigure their internal and external resources, procedures, and business skills to cope up with the shifts in the business environment. These dynamic capabilities bring innovation in the quality of productivity, and services, in technology, management decisions, and strategies to attain competitive advantages over business rivals in the market. Firms' organizational effectiveness is likely to be achieved if the managerial and business procedures are being designed and run effectively, and there is fast development in the business technology and its assets which is possible by the adoption of dynamic capabilities. The research on the organizational effectiveness of the cellular communication companies in Jordon represents that Dynamic capabilities approach helps organize the business procedures, managerial strategies, practices, and improving employees' skills, as it promotes learning and attainment of information by developing integration among business units, and between the organizations and outsiders like suppliers, customers, and other stakeholders. It brings newness in the form of better organization, and efficient arrangement of resources, strategies, procedures, and production process and in the marketing strategies and marketing procedures as well [36].

The term Ambidexterity has been derived from two Latin words, "Ambi" and" dexterity". Ambi means both while dexterity means skillfulness or agility. It was Duncan who used the term dexterity for the first time in the organizations. He said assertively that the organizations have to strategically respond to the market changing, business environment changes, and other changes but at the same, it should also carry out their activities most effectively and efficiently. Thus organizational ambidexterity means the ability of the organizations to pay heed on current responsibilities and duties and to be ready to take advantage of future opportunities as well. It is considered as the key to the firms' organizational effectiveness and their success [3]. As approved by renowned scholars, business organizations can survive only if they succeed in maintaining effectiveness in the present business environment and they are capable to compete in the business world in the future.

The present business environment is pregnant with continuous changing events that are complex, scattered, uncertain, turbulent, highly fast, highly pressured, and hyper-competitive. It is widely agreed that firms must struggle to achieve competitive advantages for survival in the business world. Most of the study conducted on the market competition throws light on the point that though it is a desirable ideal to have a sustainable 
competitive advantage, yet the majority of the business firms do not enjoy a sustainable competitive advantage in the real world. Despite all, many firms succeed in achieving competitive advantage by attaining organizational effectiveness through organizational ambidexterity. Such business enterprises perform their functions effectively sensing and responding to present business changes and they manage their policies and strategies in such manner as they can survive and compete in future circumstances. Thus organizational ambidexterity contributes a lot to the firm's organizational effectiveness [7].

This paper focuses on the impacts of firms' organizational ambidexterity on dynamic capabilities. The contribution of firms' organizational ambidexterity (OA) to designs, structure, and implementation of dynamic capabilities (DCs) is of considerable value for the survival and organizations in present as well as in the future. Organizational ambidexterity puts stress on business management to organize its policies, procedures, and functions to perform in the business world effectively according to the changing requirements. For this purpose adopt and implement appropriate dynamic capabilities in its operations [29]. The research over the past few decades shed light on the fact that design, structural nature, and effectiveness of the dynamic capabilities are positively modified by the implementation of organizational ambidexterity in the firms. The business resources and operational and production procedures are integrated and arranged appropriately to be deployed optimally to meet the requirement of organizational ambidexterity. For the achievement of organizational ambidexterity, there is created a sound information system that creates awareness in the managers and employees of available and expected opportunities for competitive advantage and present and expected changes in the business environment, market policies, customer demands, technology, and procedural techniques. Organizational ambidexterity (OA) contributes to the dynamic capabilities approach as it promotes exploration and exploitation in organizations as proved by the theoretical and empirical records of cellular communication companies in Jordon. Under the head of the exploration it promotes research, variation, experimentation, flexibility in the business environment, discovery and innovation, while in the context of exploitation it brings refinement in resources and production procedures, it creates right decision making at the right time, and it creates efficiency in the implementation and execution of capabilities [12].

In this paper we test the impacts of dynamic capabilities (DCs) on firms' organizational effectiveness (OE), the mediating effects of organizational ambidexterity on DCs and OE with the evidential support from the statements of cellular communication companies in Jordon

\section{Literature Review}

\subsection{Dynamic capabilities have a positive association with organizational effectiveness of cellular communication companies in Jordan}

The popular scholars are of the view that the survival and success of a business enterprise are dependent on its organizational effectiveness. The achievement of business goals is possible if the different organizational areas are functioning effectively. Recent research has highlighted that the achievement of competitive advantages is dependent on the fact of how effectively firms' resources, strategies, and production procedures are organized to achieve business goals [26]. In today's emerging economies, changes and shifts occur day by day in the business environment, market policies, investment sectors, technology, production technique, and customer preferences. So, business enterprises, for survival and success, are forced to sense the changes and carry out their functions effectively keeping pace with the shifts in the business environment. For the effective performance of organizational functions, organizations implement and execute several core capabilities, dynamic capabilities that enable them to cope up with the changing market demands effectively [20]. These dynamic capabilities are proving to be beneficial in organizing business resources and procedures in efficient manners to deploy them to the maximum extent. These dynamic capabilities ensure organizational effectiveness as they are implemented to integrate and reconfigure, several internal and external stakeholders like suppliers, customers, shareholders, and people engaged in the marketing [24]. There is built a sound information system that helps to provide knowledge about the shifts in the business environment to make the managers able to organize business factors accordingly. Similarly, the organizational dexterity (OA) approach 
also brings improvements in organizational effectiveness. Organizational ambidexterity motivates the business management to perform their current responsibilities with great attention according to the present business environment and present market requirements along with future policies and planning to compete in future markets. Organizational ambidexterity promotes research, experiments, quick decision making, and brings innovation and speed in business procedures. A long investigation into the organizational functions and effectiveness in cellular communication has demonstrated the considerable contribution from dynamic capabilities (DCs) and organizational ambidexterity (OA), with empirical evidence.

According to Teece, Pisano, and Shuen [32], dynamic capabilities (DCs) approach is based on the resourcebased view (RBV) which focuses on the organization of the non-imitable heterogeneous resources effectively to arrange and deploy them optimally to achieve superior performance. The dynamic capabilities approach is an extension to the RBV theory as it focuses on the identification of changes in the business environment and motivates the organization to reconfigure and integrate the resources and business procedures to cope up with the changes and on achieving competitive advantages. Recent research proves that the implementation and execution of dynamic capabilities bring organizational effectiveness in business enterprises. Much of the study conducted in this context suggests that dynamic capabilities (DCs) approach contributes to the organizational learning procedures, innovation in business management, development in production and its procedures, human resource, and intellectual property [25]. The implementation and execution of dynamic capabilities in a business organization are considered promising for the achievement of organizational effectiveness.

Eisenhardt and Martin [9] are of the view that dynamic capabilities influence firms' organizational effectiveness as they enable the firms to conduct integration among processes and procedures, their reconfiguration, acquire quality resources, and to use them optimally to achieve competitive advantages over market rivals. Zollo and Winter [39] have presented a conceptual view of dynamic capabilities with the focus on organizational learning. To them, Dynamic capabilities have adaptive, absorptive, and innovative capability elements. It contributes to the firms' organizational effectiveness at initial, developing, and maturity level. It is a recent agreement by scholars that companies detect opportunities to raise the level in market and threat, develop learning, research, exploration, analysis of technological possibilities, consumers' requirements, and structural change in markets and competitors. And it is to be checked how suppliers, customers, and competitors will react to the changes, and restrictions in context are also judged. In this situation, it is needed to adopt a new process, create new products, and make developments in services. Improvements in business practices, technological skills, and creation, as well as the development of strategies regarding investment decisions, are key elements of dynamic capabilities (DCs) [18]. Reconfiguration of organizational structures and alignment with technological and market changes are useful for organizational effectiveness.

\subsection{Organizational ambidexterity has a positive association with the organizational effectiveness of cellular communication companies in Jordan}

This piece of literature focuses on the influence of organizational ambidexterity on the firms' organizational effectiveness. Organizational ambidexterity $(\mathrm{OA})$ is the ability of business organizations to respond strategically to the shifts in business, market, and customers' demands in the most effective ways. Organizational ambidexterity (OA) makes the organization's ability to perform present business activities with full attention and to make them capable to compete in the market in the future [22]. From the points of view of different scholars, organizational ambidexterity is the key source of organizational effectiveness and success. Even the survival of the business organizations is possible if they organize their resources and business procedures effectively according to present requirements and they are ready to welcome and cope up with the future business requirements. Organizational ambidexterity can be considered as flying a plane while configuring its engine at the same [15]. Some scholars have defined OA as the firms' capabilities to explore and exploit at the same time, and this is still a common definition [30]. Long term research has highlighted the companies' need to explore and exploit simultaneous, maintaining a balance between the two. Exploration and 
exploitation that are conducted by companies, sense and respond to the current and expected changes in the business environment. Organizational ambidexterity contributes a lot to firms' organizational effectiveness as it promotes learning logistics [13], innovation development [17], and knowledge strategies that are considered significant for the achievements of organizational learning. The facts and figures from the record of cellular communication companies in Jordon represent the considerable significance of the organizational ambidexterity (OA) in achieving organizational effectiveness in the form of development in learning logistics, techniques, technology, and innovation development. OA enables the firms to develop team functioning among the company's employees, in leadership and strategic instructions to them for superior performance that strengthens the organizational effectiveness [31]. Organizational ambidexterity focuses on the companies' inclination to explore for the performance of current business responsibilities considering the present shifts in requirements and for the designing and structuring practices and strategies to cope up with the emerging future requirements.

Organizational ambidexterity contributes to the firms' organization as research is conducted by Junni, Sarala, Taras, and Tarba [16] to identify changes in business environments, novelty is brought in business strategies and processes, radical changes are identified, and different experiments are done to test the effectiveness of organizational strategies. I addition to this, new products are created to meet the customers' demands, new procedures are implemented towards the market shifts, and innovative quality is created in the services rendered that improves the organizational performance [28]. Organizational ambidexterity affects the organizing capacity of the firms stressing on exploitation in the organization of resources and procedures. Much of the study on the business organizational effectiveness support the idea that the continuous improvement in the managerial, operational and production procedures, modification in the arrangement of resources and technology, refinement and increase in the production of goods and services bring improvement in the organizational effectiveness of firms [14]. The implementation and execution of the organizational ambidexterity approach have contributed much to the organizational effectiveness of the cellular communication companies in Jordon. These organizations pay heed on the present requirement of the business environment, market changes, and customers present expectations, they perform their current business responsibilities with full attention. But at the same time, they keep an eye on future requirements, changes, and customer expectations and create the ability to compete in the future markets.

\subsection{Organizational ambidexterity has played a positive mediation role among the nexus of dynamic capabilities and organizational effectiveness}

The organizational ambidexterity (OA) approach forces on the implementation and execution of the dynamic capabilities. This study is devoted to highlighting the interrelationship of DCs and OA in identifying the changes, capturing the shifts in market and technology, and reconfiguring firms' resources, strategies, policies, and procedures [5]. There are common strategies and practices found in the concepts of organizational ambidexterity and dynamic capabilities. Organizational ambidexterity (OA) approach influences on the dynamic capabilities (DCs) approach. Firm's organizational ambidexterity considerably contributes to designing, structure, implementation, and execution of dynamic capabilities (DCs) for the survival and achievement of organizational effectiveness in the present and future as well. On the other hand, dynamic capabilities also influence the implementation of organizational ambidexterity in organizations. Al-Aali \& Teece [2], in their studies highlight that the motive of organizational ambidexterity is to make business organizations able to perform present responsibilities in response to the shifts in the business environment and make preparation for the achievement of competitive advantage in the future. The approach of dynamic capabilities ensures the achievement of that motive of organizational ambidexterity. Dynamic capabilities (DCs) approach provide sound procedures to detect the shifts in the business environment, rapid changes in the market, customers' preferences, and changes in technology. It creates awareness of competitors', suppliers', and consumers' behavior towards the above-mentioned changes. Having the proper knowledge and awareness business organization can make the right decisions at the right time and perform activities accordingly. Dynamic capabilities are effective in both exploration and exploitation [19]. Research campaigns are carried out, variation is brought in the organizational procedures, and several procedures are launched for 
discovery and innovation in the production. Experiments are undertaken to test the effectiveness of alternatives, and flexibility is created in the business environment. The dynamic capabilities approach shares a lot of strategies and practices with those of the organizational ambidexterity approach.

\section{Method}

The current research has the goal to investigate the impact of dynamic capabilities on the organizational effectiveness of cellular communication firms in Jordan. The examination of the mediating role of organizational ambidexterity among the nexus of dynamic capabilities and organizational effectiveness is also included in the objectives of the current study. The quantitative method of data gathering has been utilized to collect the data from the employees of the cellular communication firms that are currently operating in Jordan. For distributing the surveys, a personal visit has to be executed to the cellular communication firms and forwarded around 410 surveys to the respondents. After three weeks, only 300 questionnaires have been received and used for analysis that has about response rate of 73.17 percent. The framework of the ongoing study is complex and that is the reason the AMOS has been used for the purpose of analysis because it provides the best estimation in this case [23]. This study has used the two dimensions of dynamic capabilities as predictors such as exploitation capability (EC) and exploration capability (EXC) that has five items each [21]. In addition, the ongoing study also used the organizational ambidexterity (OAD) as the mediator that has eleven items [21]. Finally, the current research also has taken the organizational effectiveness (OE) as a predictive variable that has ten items [1]. These questionnaires have been highlighted in Table 1, Table 2 and Table 3 given below, while the constructs along with links are attached in the framework that is also highlighted in Figure 1.

Table. 1. Scale of Dynamic Capabilities

\begin{tabular}{llll}
\hline Dimensions & Items & Statements & Sources \\
\hline $\begin{array}{l}\text { Exploitation } \\
\text { Capability }\end{array}$ & EC1 & $\begin{array}{l}\text { The upgrade of current knowledge and skills of the familiar products } \\
\text { and technologies } \\
\text { The upgrade of skills in product development processes that the firm } \\
\text { already has significant experience in it. } \\
\text { Faizal, 2014) } \\
\text { The strengthening of knowledge and skills that improve the } \\
\text { efficiency of existing activities for innovation } \\
\text { The investment in skills enhancement of processes to improve the } \\
\text { innovation productivity of current mature technologies } \\
\text { The enhancement of competencies in searching for solutions to } \\
\text { customers problems that are near to the existing solutions } \\
\text { Capability }\end{array}$ \\
EC5 & EXC2 & $\begin{array}{l}\text { The acquisition of manufacturing technologies and skills that are } \\
\text { entirely new to the firm } \\
\text { The acquisition of entirely new managerial and organizational skills } \\
\text { that are important for innovation } \\
\text { Learning of product development processes that are entirely new to } \\
\text { the industry } \\
\text { Learning of the new skills in areas such as funding new technology, } \\
\text { staffing R\&D function, training and development of R\&D, and } \\
\text { engineering personnel for the first time } \\
\text { The strengthening of innovation processes in the areas where a firm } \\
\text { had no prior experience }\end{array}$ \\
EXC3
\end{tabular}

Table. 2. Scale of Organizational Ambidexterity

\begin{tabular}{lll}
\hline Items & Statements & Sources \\
\hline OAD1 & The structural differentiation & Mohamad
\end{tabular}


OAD2 The units that are specialized in specific functions

OAD3 The units that are focused on either short or long term objectives

OAD4 The line and staff departments that are structurally separated within the organization

OAD5 The innovation and production activities that are structurally separated within the organization

OAD6 The customers" needs that are served from separate departments

OAD7 Take initiative and alert to opportunities beyond the confines of your jobs

OAD8 Seek out opportunities and cooperative to combines your efforts with others

OAD9 Act as a broker who always looking to build internal linkages

OAD10 Act as a multi-tasker who comfortable wearing more than one ,hat ${ }^{\text {ee }}$

OAD11 The individual who refine and renew their knowledge, skills, and expertise

Table. 3. Scale of Organizational Effectiveness

\begin{tabular}{|c|c|c|}
\hline Items & Statements & Sources \\
\hline OE1 & $\begin{array}{l}\text { I would be very happy to spend the rest of my career with this } \\
\text { organization. }\end{array}$ & $\begin{array}{l}\text { (Abuowda, } \\
2010)\end{array}$ \\
\hline OE2 & I feel as if this organization's problem as my own. & \\
\hline OE3 & $\begin{array}{l}\text { Even if this organization is not paying to me well, I well still to be } \\
\text { reluctant to change to other organization. }\end{array}$ & \\
\hline OE4 & I feel emotionally attached to this organization. & \\
\hline OE5 & This organization deserve my loyalty. & \\
\hline OE6 & $\begin{array}{l}\text { I am willing to put in a great effort beyond the normally expected to help } \\
\text { this organization to be successful. }\end{array}$ & \\
\hline OE7 & $\begin{array}{l}\text { Too much in my life would be disturbed if I decide to leave my } \\
\text { organization now. }\end{array}$ & \\
\hline OE8 & I feel a strong sense of belonging to my organization. & \\
\hline OE9 & I do feel like "part of my family" at my organization. & \\
\hline OE10 & I would feel guilty if I leave my organization now. & \\
\hline
\end{tabular}

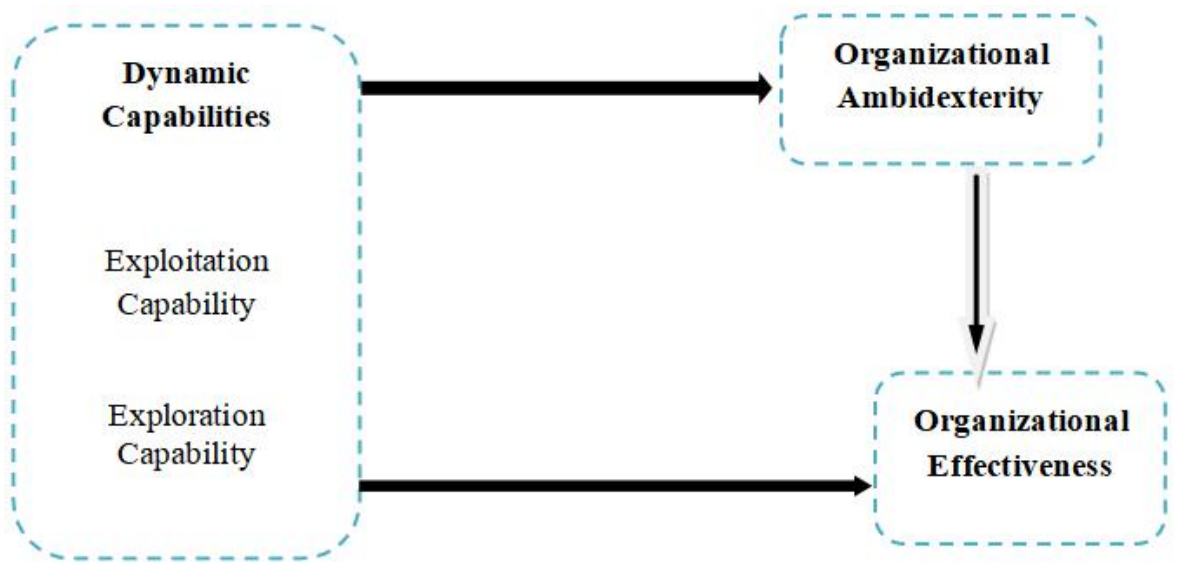

Fig. 1. Theoretical Framework 


\section{Findings}

The findings of the ongoing study show firstly the convergent validity that exposes the links among the items of the constructs. The results have shown that high linkage among the items and convergent validity proved as valid because the loading along with AVE is larger than 0.50 while CR values have been higher than 0.70 . These values have been shown in Table 4.

Table. 4. Convergent validity

\begin{tabular}{|c|c|c|c|c|}
\hline Constructs & Items & Loadings & $\mathbf{C R}$ & AVE \\
\hline \multirow[t]{6}{*}{ Exploitation Capability } & EC5 & 0.818 & 0.902 & 0.652 \\
\hline & $\mathrm{EC} 4$ & 0.696 & & \\
\hline & $\mathrm{EC} 3$ & 0.690 & & \\
\hline & $\mathrm{EC} 2$ & 0.990 & & \\
\hline & $\mathrm{EC} 1$ & 0.805 & & \\
\hline & EXC5 & 0.989 & 0.919 & 0.700 \\
\hline \multirow[t]{4}{*}{ Exploration Capability } & EXC4 & 0.682 & & \\
\hline & EXC3 & 0.673 & & \\
\hline & EXC2 & 0.995 & & \\
\hline & EXC1 & 0.782 & & \\
\hline \multirow[t]{10}{*}{ Organizational Effectiveness } & OE10 & 0.980 & 0.909 & 0.515 \\
\hline & OE9 & 0.568 & & \\
\hline & OE8 & 0.577 & & \\
\hline & OE7 & 0.985 & & \\
\hline & OE6 & 0.748 & & \\
\hline & OE5 & 0.702 & & \\
\hline & OE4 & 0.763 & & \\
\hline & OE3 & 0.576 & & \\
\hline & OE2 & 0.418 & & \\
\hline & OE1 & 0.651 & & \\
\hline \multirow[t]{11}{*}{ Organizational Ambidexterity } & OAD11 & 0.421 & 0.924 & 0.540 \\
\hline & OAD10 & 0.379 & & \\
\hline & OAD9 & 0.522 & & \\
\hline & OAD8 & 0.741 & & \\
\hline & OAD7 & 0.823 & & \\
\hline & OAD6 & 0.841 & & \\
\hline & OAD5 & 0.858 & & \\
\hline & OAD4 & 0.793 & & \\
\hline & OAD3 & 0.832 & & \\
\hline & OAD2 & 0.841 & & \\
\hline & OAD1 & 0.806 & & \\
\hline
\end{tabular}

The findings of the study also show the discriminant validity that exposes the links among the variables. The results have shown that no high linkage among the variables and discriminant validity proved as valid because the figures that exposed the link with construct itself are larger than the figures that exposed the nexus with other variables. These values have been shown in Table 5 . 
A. Aziz, R. Zaki \& U. Syed Ehsan/ IJIIS Vo1. 3 No. 2 September 2020, pp. 81-93

Table. 5. Discriminant validity

\begin{tabular}{lcccc}
\hline & OE & EC & EXC & OAD \\
\hline OE & 0.718 & & & \\
EC & 0.128 & 0.807 & & \\
EXC & 0.116 & 0.688 & 0.836 & 0.735 \\
OAD & 0.359 & 0.172 & 0.159 & \\
\hline
\end{tabular}

The findings exposed that the model that has been used by the ongoing study is fit for analysis because the values of CFI and GFI are more than 0.90. In addition, the values of AGFI, NFI are larger than 0.80. Moreover, the value of CMIN/DF is between 1 to 5 while, however, the values of RMR and RNSEA are less than 0.80 and the value of PGFI is higher than 0.50 that have been evidence of the model fit of the study. These figures have been shown in Table 6.

Table. 6. Model Fit

\begin{tabular}{lccc}
\hline Fit Index & Admissibility & Result & Fit (Yes/No) \\
\hline CMIN/DF & $1.00-5.00$ & 3.906 & Yes \\
CFI & $>0.90$ & 0.912 & Yes \\
GFI & $>0.90$ & 0.905 & Yes \\
AGFI & $>0.80$ & 0.825 & Yes \\
PGFI & $>0.50$ & 0.591 & Yes \\
RMR & $<0.80$ & 0.388 & Yes \\
NFI & $>0.80$ & 0.815 & Yes \\
RMSEA & $<0.80$ & 0.145 & Yes \\
\hline
\end{tabular}

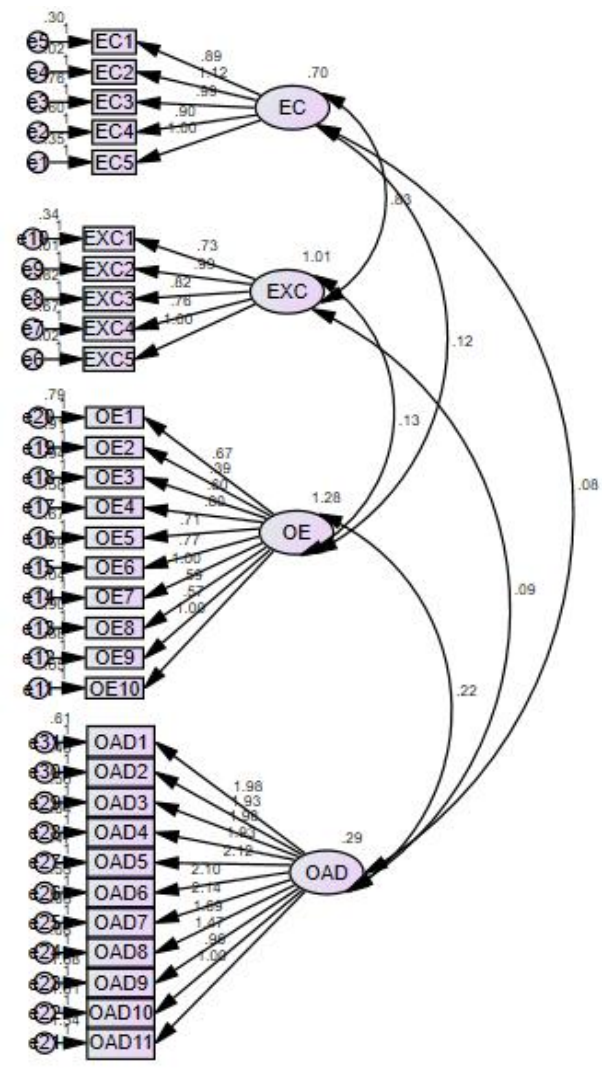

Fig. 2. Measurement model assessment

The results of the present research highlighted that all the dimensions of dynamic capabilities such as exploitation capability and exploration capability have positively associated with organizational effectiveness 
and accept H1. In addition, these results also exposed that the organizational ambidexterity also has positive nexus with the organizational effectiveness and accept $\mathrm{H} 2$. These links are highlighted in Table 7 and Figure 3.

Table. 7. Direct and Indirect Effects

\begin{tabular}{lllcccc}
\hline Relationships & & & Beta & S.D. & t-statistics & p-values \\
\hline OAD & $<---$ & EC & 0.408 & 0.369 & 1.105 & 0.269 \\
OAD & $<---$ & EXC & -0.251 & 0.306 & -0.823 & 0.411 \\
OE & $<---$ & EC & 0.422 & 0.206 & 2.049 & 0.045 \\
OE & $<---$ & EXC & 0.278 & 0.085 & 3.271 & 0.035 \\
OE & $<---$ & OAD & 0.726 & 0.155 & 4.681 & $* * *$ \\
\hline
\end{tabular}

The results also highlighted that organizational ambidexterity positively mediates among the links of all the dimensions of dynamic capabilities such as exploitation capability and exploration capability and organizational effectiveness and accept $\mathrm{H} 3$. These links are highlighted in Table 8.

Table. 8. Mediating Effects

\begin{tabular}{lccc}
\hline Relationships & Beta & L.L. & U.L. \\
\hline OE $<--$ OAD $<--E C$ & 0.219 & 0.097 & 0.137 \\
OE<--OAD $<--E X C$ & 0.162 & 0.676 & 0.734 \\
\hline
\end{tabular}

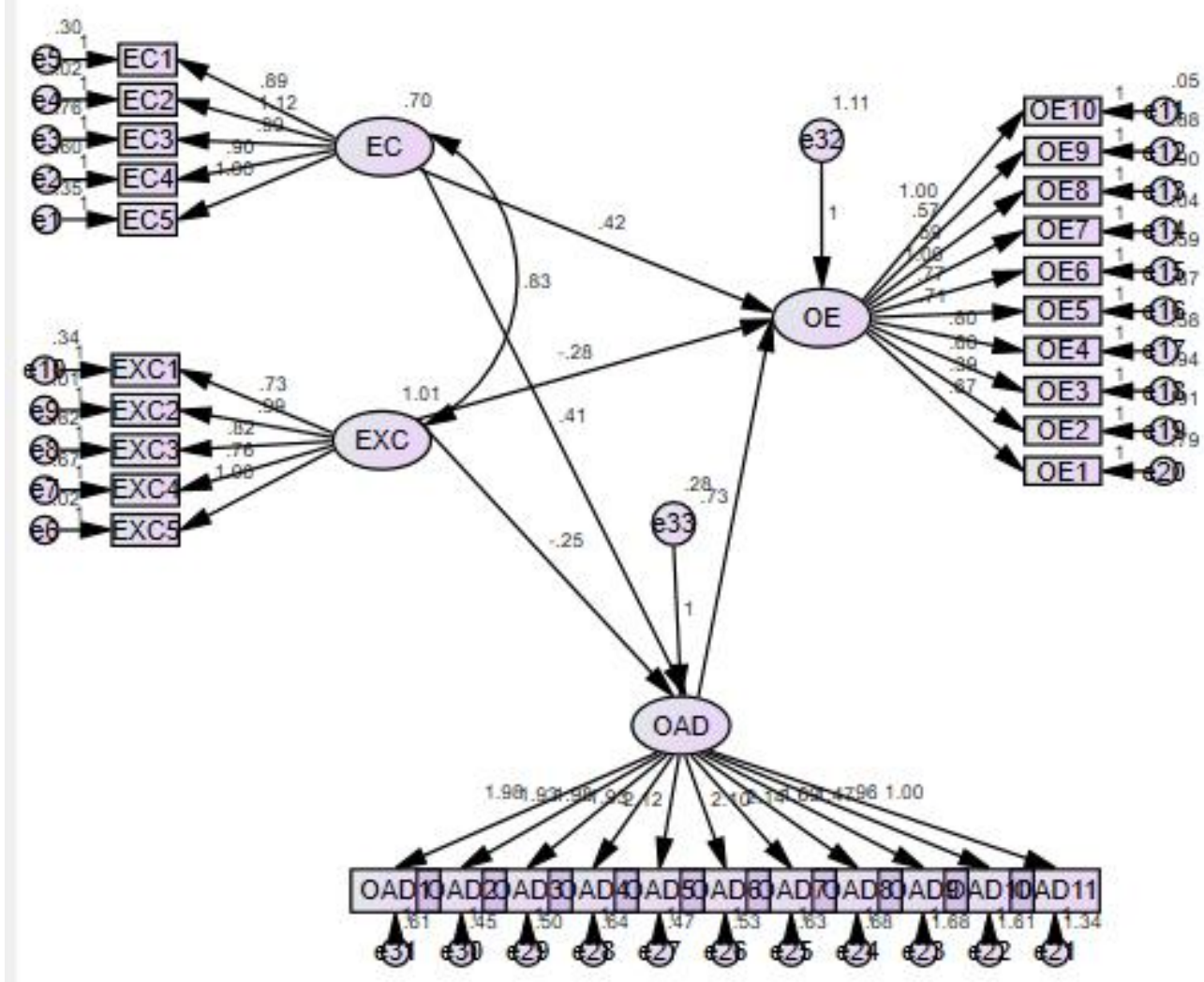

Fig. 3. Structural model assessment

\section{Discussion}

The results exposed that the positive nexus has been found among the nexus of dynamic capabilities, organizational ambidexterity, and organizational effectiveness. These outcomes are matched with the results of Úbeda-García, Claver-Cortés, Marco-Lajara, Zaragoza-Sáez, and García-Lillo [35] who also investigated that the dynamic capabilities have positively affected the organizational effectiveness. A study conducted by 
Úbeda-García, Claver-Cortés, Marco-Lajara, and Zaragoza-Sáez [34] examined the organizational ambidexterity along with dynamic capabilities could increase the effectiveness of the organization and this could be similar to the outcome of the ongoing research. The results also revealed that the organizational ambidexterity has positive mediating among the links of dynamic capabilities such as exploitation capability and exploration capability on organizational effectiveness. These outputs are also same as the outcomes of [27] who also exposed the effectiveness of the organization could depend on the dynamic capabilities along with the organizational ambidexterity. The capabilities of the organization could improve the effectiveness of the organization because the positive and effective capabilities always put the positive impact of the organization on its employee along with customers that enhance its effectiveness among the society and this could be similar to the current study outcomes. In addition, the effective capabilities along with characteristics of ambidexterity could improve the financial performance along with the effectiveness of the organization among the employees as well as customers [6] and this argument has similarity with the findings of present study.

These findings are suitable for the regulation developing authorities that they should develop and implement the effective regulation related to the dynamic capabilities and organizational ambidexterity that enhance the organizational effectiveness of the firm. This study has providing the help to the implementation authorities that how they should implement the necessary policies related to the capabilities and organizational effectiveness in the organization. In addition, the present study has contributed among the literature of the dynamic capabilities and its impact on the effectiveness of the organization. Moreover, this study has also contributed to the literature of the organizational ambidexterity along with its mediating role among the links of dynamic capabilities and organizational effectiveness. Finally, this study has implemented in the cellular communication companies of Jordan and related countries that has same condition as in Jordan regarding the dynamic capabilities and effectiveness of the organization.

\section{Conclusion}

Thus, the conclusion has drawn by the study that the cellular communication companies of Jordan have effective dynamic capabilities that enhance the firm effectiveness in the country. In addition, these companies also have characteristics of strong organizational ambidexterity that could also increase the effectiveness of the cellular communication companies of Jordan. These ambidexterity characteristics of the organization related to the cellular companies in Jordan has played a vital role in the development of the organization that enhance its effectiveness. The present study has ignored the other companies that cellular communication companies and suggested that future studies should add other companies then cellular communication companies. Finally, the present study has taken limited predictors such as only two dimensions of the dynamic capabilities and recommended that upcoming studies should focus on other predictors in their studies.

\section{References}

[1] Abuowda, A. (2010). The Relationship Between Transformational Leadership Style and Organizational Effectiveness in United Nations Development Programme/Programme of Assistance to the Palestinian People UNDP/PAPP. Universiti Utara Malaysia.

[2] Al-Aali, A., \& Teece, D. J. (2014). International entrepreneurship and the theory of the (Long-Lived) international firm: a capabilities perspective. Entrepreneurship Theory and Practice, 38(1), 95-116.

[3] Andriopoulos, C., \& Lewis, M. W. (2009). Exploitation-exploration tensions and organizational ambidexterity: Managing paradoxes of innovation. Organization science, 20(4), 696-717.

[4] Barney, J. B. (1986). Strategic factor markets: Expectations, luck, and business strategy. Management science, 32(10), 1231-1241.

[5] Beckman, C. M. (2006). The influence of founding team company affiliations on firm behavior. Academy of management Journal, 49(4), 741-758.

[6] Bustinza, O. F., Vendrell-Herrero, F., Perez-Arostegui, M. N., \& Parry, G. (2019). Technological capabilities, resilience capabilities and organizational effectiveness. The International Journal of Human Resource Management, 30(8), 1370-1392. 
[7] Daniel, E. M., \& Wilson, H. N. (2003). The role of dynamic capabilities in e-business transformation. European Journal of Information Systems, 12(4), 282-296.

[8] Dunham, N. C., Kindig, D. A., \& Schulz, R. (1994). The value of the physician executive role to organizational effectiveness and performance. Health care management review, 19(4), 56-63.

[9] Eisenhardt, K. M., \& Martin, J. A. (2000). Dynamic capabilities: what are they? Strategic management journal, 21(11), 1105-1121.

[10] Frankel, E. G. (2008). Organizational Effectiveness and Performance. Quality Decision Management-The Heart of Effective Futures-Oriented Management: A Primer for Effective Decision-Based Management, 14(3), 43-47.

[11] Gibson, C. B., \& Birkinshaw, J. (2004). The antecedents, consequences, and mediating role of organizational ambidexterity. Academy of management Journal, 47(2), 209-226.

[12] Griffith, D. A., \& Harvey, M. G. (2001). A resource perspective of global dynamic capabilities. Journal of international business studies, 32(3), 597-606.

[13] He, Z.-L., \& Wong, P.-K. (2004). Exploration vs. exploitation: An empirical test of the ambidexterity hypothesis. Organization science, 15(4), 481-494.

[14] Im, G., \& Rai, A. (2008). Knowledge sharing ambidexterity in long-term interorganizational relationships. Management science, 54(7), 1281-1296.

[15] Judge, W. Q., \& Blocker, C. P. (2008). Organizational capacity for change and strategic ambidexterity. European Journal of Marketing, 42(9), 915-926.

[16] Junni, P., Sarala, R. M., Taras, V., \& Tarba, S. Y. (2013). Organizational ambidexterity and performance: A metaanalysis. Academy of Management Perspectives, 27(4), 299-312.

[17] Katila, R., \& Ahuja, G. (2002). Something old, something new: A longitudinal study of search behavior and new product introduction. Academy of management Journal, 45(6), 1183-1194.

[18] Killen, C. P., Jugdev, K., Drouin, N., \& Petit, Y. (2012). Advancing project and portfolio management research: Applying strategic management theories. International journal of project management, 30(5), 525-538.

[19] Maijanen, P., \& Virta, S. (2017). Managing exploration and exploitation in a media organisation-A capability-based approach to ambidexterity. Journal of Media Business Studies, 14(2), 146-165.

[20] Malik, M. E., Ghafoor, M. M., \& Naseer, S. (2011). Organizational effectiveness: A case study of telecommunication and banking sector of Pakistan. Far east journal of psychology and business, 2(1), 37-48.

[21] Mohamad Faizal, A. Z. (2014). Organisational learning, organisational ambidexterity, environmental turbulence, and NPD performance of Malaysian's manufacturing sector. Universiti Utara Malaysia.

[22] O'Reilly 3rd, C. A., \& Tushman, M. L. (2004). The ambidextrous organization. Harvard business review, 82(4), 7479.

[23] Ong, M. H. A., \& Puteh, F. (2017). Quantitative data analysis: Choosing between SPSS, PLS, and AMOS in social science research. International Interdisciplinary Journal of Scientific Research, 3(1), 14-25.

[24] Ostroff, C., \& Schmitt, N. (1993). Configurations of organizational effectiveness and efficiency. Academy of management Journal, 36(6), 1345-1361.

[25] Parayitam, S., \& Guru, K. (2010). Economics of resource based and dynamic capabilities view: A contemporary framework. Academy of Strategic Management Journal, 9(1), 83-89.

[26] Parhizgari, A., \& Gilbert, G. R. (2004). Measures of organizational effectiveness: private and public sector performance. Omega, 32(3), 221-229.

[27] Peng, M. Y.-P., Zhang, Z., Yen, H.-Y., \& Yang, S.-M. (2019). Dynamic Capabilities and Firm Performance in the High-Tech Industry: Quadratic and Moderating Effects under Differing Ambidexterity Levels. Sustainability, 11(18), 1-15.

[28] Rao-Nicholson, R., Khan, Z., Akhtar, P., \& Tarba, S. Y. (2020). The contingent role of distributed leadership in the relationship between HR practices and organizational ambidexterity in the cross-border M\&As of emerging market multinationals. The International Journal of Human Resource Management, 31(2), 232-253.

[29] Schoemaker, P. J., Heaton, S., \& Teece, D. (2018). Innovation, dynamic capabilities, and leadership. California Management Review, 61(1), 15-42.

[30] Simsek, Z. (2009). Organizational ambidexterity: Towards a multilevel understanding. Journal of Management Studies, 46(4), 597-624.

[31] Taylor, A., \& Greve, H. R. (2006). Superman or the fantastic four? Knowledge combination and experience in innovative teams. Academy of management Journal, 49(4), 723-740.

[32] Teece, D. J., Pisano, G., \& Shuen, A. (1997). Dynamic capabilities and strategic management. Strategic management journal, 18(7), 509-533.

[33] Torres, R., Sidorova, A., \& Jones, M. C. (2018). Enabling firm performance through business intelligence and analytics: A dynamic capabilities perspective. Information \& Management, 55(7), 822-839. 
A. Aziz, R. Zaki \& U. Syed Ehsan/ IJIIS Vo1. 3 No. 2 September 2020, pp. 81-93

[34] Úbeda-García, M., Claver-Cortés, E., Marco-Lajara, B., \& Zaragoza-Sáez, P. (2020). Toward a dynamic construction of organizational ambidexterity: Exploring the synergies between structural differentiation, organizational context, and interorganizational relations. Journal of Business Research, 112, 363-372.

[35] Úbeda-García, M., Claver-Cortés, E., Marco-Lajara, B., Zaragoza-Sáez, P., \& García-Lillo, F. (2018). High performance work system and performance: Opening the black box through the organizational ambidexterity and human resource flexibility. Journal of Business Research, 88, 397-406.

[36] Wu, Q., He, Q., Duan, Y., \& O'Regan, N. (2012). Implementing dynamic capabilities for corporate strategic change toward sustainability. Strategic Change, 21(5), 231-237.

[37] Yukl, G. (2008). How leaders influence organizational effectiveness. The leadership quarterly, 19(6), 708-722.

[38] Zahra, S. A., \& George, G. (2002). The net-enabled business innovation cycle and the evolution of dynamic capabilities. Information systems research, 13(2), 147-150.

[39] Zollo, M., \& Winter, S. G. (2002). Deliberate learning and the evolution of dynamic capabilities. Organization science, 13(3), 339-351. 